\title{
Vakava eläintautikriisi Suomessa: Sianlihan hinnan muutos ja tuottajien menetykset lyhyellä aikavälillä
}

\author{
Jarkko Niemi ja Heikki Lehtonen \\ Maa- ja elintarviketalouden tutkimuskeskus, taloustutkimus, Luutnantintie 13, 00410 Helsinki, \\ etunimi.sukunimi@mtt.fi
}

\section{Johdanto}

Herkästi leviävät eläintaudit voivat aiheuttaa merkittäviä taloudellisia vahinkoja lihantuotantoketjulle (mm. Mangen 2002, Mahul ja Durand 2000). Taloudellisia vahinkoja voi aiheuttaa muun muassa se, että kansainväliset sopimukset antavat muille maille oikeuden kieltäytyä vastaanottamasta eläinperäisiä tuotteita Suomesta, kun maassamme on havaittu jotain kansainvälisen eläintautijärjestön OIE:n Alistalla mainittua eläintautia. Tällaisia tauteja ovat muun muassa suu- ja sorkkatauti ja klassinen sikarutto. Eläintaudin esiintyminen yhdellä tilalla voi aiheuttaa ulkoisvaikutuksia koko elinkeinolle, sillä jo yksi tartunnan saanut eläin voi rajoittaa lihan vientiä Suomesta usean kuukauden ajan. Muiden maiden asettamat tuontirajoitukset voikin aiheuttaa Suomen lihamarkkinoilla ylitarjontatilanteen, jossa vientiin tarkoitettu liha (pois lukien infektoituneet ja lopetetut eläimet, jotka eivät päädy markkinoille) on kulutettava kotimaassa (Dijkhuizen ym. 1994).

Aikaisempien tutkimusten mukaan tuontirajoitusten merkitys on erityisen suuri silloin, kun huomattava osa tuotteesta menee vientiin (Saatkamp ym. 2000). Runsaasti elintarvikevientiä harjoittavissa maissa tuojamaiden reaktiot voivatkin vaikuttaa merkittävästi herkästi tarttuvan eläintaudin taloudellisiin seurauksiin (mm. Mangen 2002). Lisäksi maataloustuotantoon liittyvät viiveet tai muut tekijät voivat aiheuttaa sen, että esimerkiksi hintavaihtelu vaikutukset jatkuvat pitkään (van Asseldonk ym. 2000). Aikaisempien tutkimusten perusteella näyttää myös siltä, että viejämaalle on taloudellisesti järkevää vähentää eläinperäisten tuotteiden ulkomaankauppaan liittyviä rajoituksia. Viejämaa voi jossain määrin hallita tuontirajoituksia rajaamalla tautialue erilleen muusta tuotantoalueesta (ns. regionalisointi) (OIE 2001). Suhteellisen pienille elintarvikkeiden tuottaja- ja viejämaille, kuten Suomelle, herkästi leviävän eläintaudin aiheuttamista taloudellisista menetyksistä on kuitenkin vain vähän tietoa. Pienessäkin viejämaassa tuontirajoitukset voivat aiheuttaa tuottajille huomattavia tulonmenetyksiä, ja niiden vaikutukset voivat olla vaikeasti poistettavissa. Onkin mahdollista, että jakeluketjun toimintaan panostaminen on taloudellisesti järkevää myös Suomessa.

Tämän tutkimuksen tavoitteena on selvittää, mitä vaikutuksia vientikysynnän muutokset voisivat aiheuttaa Suomen sianlihamarkkinoilla lyhyellä aikavälillä. Tutkimuksessa estimoidaan sianlihan kysyntäfunktiot Suomessa kulutetulle kotimaiselle ja ulkomaiselle sianlihalle sekä Suomesta viedylle sianlihalle. Estimoiduista kysyntäyhtälöistä ratkaistaan kuluttajien hintareaktiofunktio, jonka avulla simuloidaan sianlihan tuottajahinnan muutos lyhyellä aikavälillä erilaisissa tautiskenaarioissa.

\section{Aineisto ja menetelmät}

Sikamarkkinoiden toimintaa voidaan kuvata tasapainoyhtälöllä, jossa kaikki markkinoille tuotettu liha kulutetaan samalla periodilla (Buijtels ja Burrell 2000):

(1) $D_{t}=S_{t}+D_{t}^{i m}-D_{t}^{e x}$,

jossa $D_{t}$ on kokonaiskysyntä Suomessa kulutetulle sianlihalle, $S_{t}$ on Suomessa tuotetun sianlihan määrä, $D_{t}^{i m}$ on Suomeen tuodun sianlihan määrä ja $D_{t}^{e x}$ on Suomesta ulkomaille viedyn sianlihan määrä.

Tässä tutkimuksessa estimoidaan sianlihan kysyntä Suomessa kulutetulle kotimaiselle ja ulkomaiselle sianlihalle sekä Suomesta viedylle sianlihalle käyttäen seemingly unrelated regressionmenetelmää. Yhtälössä 1 esitettyjä kysyntämuuttujia selitetään sianlihan tuottajahinnalla Suomessa ja Tanskassa sekä eräillä muilla eksogeenisilla muuttujilla. Yhtälöt estimoidaan differenssimuodossa kuukausiaineistosta eli siten, että kysynnän muutosta kahden peräkkäisen kuukauden välillä selitetään eksogeenisten muuttujien arvoissa tapahtuneilla muutoksilla. Kysyntätiedot perustuvat maa- ja metsätalousministeriön tietopalvelukeskuksen (TIKE) ja tullihallituksen kuukausitilastoihin, sianlihan kotimainen hinta ja lihavarastojen määrä perustuvat TIKE:n tuottajahintatilastoon, lihan tuottajahinta 
Tanskassa perustuu Tanskan tilastokeskuksen tuottajahintaindeksiin ja kuluttajien tulot perustuvat Tilastokeskuksen palkansaajien ansiotasoindeksiin.

Estimoidusta kysyntäyhtälöstä ratkaistaan hintareaktiofunktio kotimaiseen kulutukseen ja vientiin päätyvän sianlihan teurastamokysynnälle. Tämän jälkeen simuloidaan lyhyen aikavälin $(6 \mathrm{kk})$ sianlihan tuottajahintaa ja kysyntää Suomessa erilaisissa tautitilanteissa siten, että tarjonta on kiinnitetty tietylle tasolle ja markkinat tyhjentyvät. Tällöin kysynnän hintareaktiofunktio määrää sen, millä hinnalla tarjottu määrä kulutetaan. Keskipitkällä tai pitkällä aikavälillä tuottajat voivat sopeuttaa tuotantopäätöksensä muuttuneen markkina- ja tautitilanteen mukaiseksi. Sopeutuminen voidaan ottaa huomioon tarkasteltaessa eläintaudin taloudellisia vaikutuksia mallintamalla porsastuottajien optimaaliset siemennyspäätökset ja niihin liittyvä karjadynamiikka. Sopeutumiskustannukset ja biologiset rajoitteet vaikuttavat kuitenkin lyhyellä aikavälillä tuotantopäätöksiin niin, että sianlihan tarjonta on lähes täysin päätetty seuraavien 9-10 kuukauden ajaksi. Lyhyellä aikavälillä mallinnusongelma muuttuukin deterministiseksi hintareaktioiden simuloinniksi.

Simulointi perustuu tammi-kesäkuun 2001 kysyntä- ja tarjontatilanteeseen. Normaalin kysyntätilanteen lisäksi tarkastellaan yhdeksää tautiskenaariota, joissa Suomessa esiintyy klassista sikaruttoa. Taudinpurkauksen vuoksi osa markkinoille tarkoitetusta lihasta hävitetään ja vientikysyntä voi alentua. Taudinpurkauksen suhteen tarkastellaan kolmea skenaariota: pieni taudinpurkaus (yksi tartunnan saanut tila), keskisuuri taudin purkaus (16 tilaa; perustuu Iso-Britannian epidemiaan vuonna 2000 (Pighealth.com 2003)) ja suuri taudinpurkaus (perustuu Alankomaiden epidemiaan vuosina 1997-1998 (Elbers ym 1999)). Lisäksi vientikysyntä voi alentua 85 \% (EU:n ulkopuolisten maiden asettama täydellinen tuontikielto suomalaiselle sianlihalle), 44\% (Suurin suomalaisen sianlihan tuojamaa (Venäjä) asettaa täydellisen tuontikiellon suomalaiselle sianlihalle) tai $0 \%$ verrattuna tilanteeseen, jossa taudinpurkausta ei havaita. Simuloituja skenaarioita verrataan tilanteeseen, jossa taudinpurkausta ei havaita. Vertailun perusteella lasketaan taudinpurkauksen kuuden ensimmäisen kuukauden aikana havaittu muutos sianlihan tuottajahinnassa ja tuottajien markkinoilta saamissa tuloissa.

\section{Tulokset ja tulosten tarkastelu}

Simulointimallin kalibrointi toteutuneisiin kysyntä- ja tarjontaolosuhteisiin antoi tulokseksi lähes saman hintakehityksen kuin markkinoilla havaittiin vuonna 2001. Tautishokin syöttäminen sikamarkkinoille lisäsi sianlihan hintavaihtelua, sillä vientikysynnän heikentyessä vientiin tarkoitetun lihamäärän kuluttaminen aiheutti ylitarjontaa kotimarkkinoilla. Lisäksi infektoituneiden tilojen eläimet eivät päätyneet markkinoille, mikä vähensi lihan tarjontaa kotimarkkinoilla.

Tautishokin aiheuttamat hintamuutokset (taulukko 1) mittaavat sitä, kuinka monta prosenttia simuloitu tuottajahinta muuttui tautishokki-skenaariossa verrattuna sianlihan tuottajahintaan $(1,56 € / \mathrm{kg})$ normaalitilanteessa kuuden kuukauden kuluttua tautishokin alkamisesta. Vastaavasti markkinoilta saadun tulon muutos mittaa, kuinka paljon tuottajien markkinoilta saamat myyntitulot (milj. euroa) muuttuivat simuloiduissa tautiskenaarioissa verrattuna normaalitilanteeseen kuuden ensimmäisen kuukauden aikana. Tulosten mukaan tuontirajoitusten sianlihan tuottajille aiheuttamat tuloja hintavaikutukset voivat olla sekä positiivisia että negatiivisia (taulukko 1). Hintamuutos toteutui vähitellen, vaikka alkushokki aiheuttikin useimmissa skenaarioissa suurimman muutoksen. Lisäksi joissain skenaarioissa hintakehitys oli epidemian alussa negatiivinen suhteessa normaaliskenaarion tuottajahinnan muutoksiin, mutta alkushokin jälkeen hinta nousi jopa korkeammaksi kuin tuottajahinta normaalitilanteessa. Esimerkiksi vientikysynnän alentuessa $44 \%$ tuottajahinta laski ensimmäisen kuukauden aikana 4,3-5 senttiä (3,1\%-3,7\%) kilolta verrattuna vastaavan ajankohdan hintaan normaaliskenaariossa. Kuuden kuukauden hintamuutos oli kuitenkin pienessä epidemiassa $-16 \mathrm{c} / \mathrm{kg}(-10,5 \%)$ ja suuressa epidemiassa $+13 \mathrm{c} / \mathrm{kg}(+8,2 \%)$.

Simuloidut tulomuutokset ovat saman suuntaisia, kuin hintamuutokset. Esimerkiksi pieni epidemia laski tuottajien tuloja enemmän $(-26,7 \%-+0,1 \%)$ kuin suuri epidemia $(-15 \%-+6,9 \%)$. Toisaalta tuontirajoitusten tiukentuminen lisäsi tuottajien tulonmenetyksiä. Kun vientikysynnässä ei tapahtunut muutoksia, tuottajien nettotulot lisääntyvät epidemian vuoksi (taulukko 1). Sekä hinta- että tulomuutoksiin vaikuttivat epidemian koko, tuontirajoitusten määrä sekä näiden kahden tekijän yhteisvaikutus. Suhteellisesti mitaten tuottajien tulot näyttävät kuitenkin muuttuvan vähemmän kuin lopputuotteen lihan tuottajahinta. 
Taulukko 1. Simuloidut hinta- ja tulomuutokset kuuden kuukauden aikana, kun epidemia on "pieni”, "keskisuuri" tai "suuri" ja vientikysyntä alenee $0 \%, 44 \%$ tai $85 \%$. Hintamuutokset on ilmoitettu muodossa €/kg lihaa (muutos (\%) suhteessa normaaliskenaarion tuottajahintaan suluissa) ja tulomuutokset miljoonina euroina (muutos $(\%)$ suhteessa normaaliskenaarion myyntituloon suluissa).

\begin{tabular}{|c|c|c|c|c|c|}
\hline Epidemian koko & Pieni & Keskisuuri & & Suuri & \\
\hline \multicolumn{6}{|c|}{ Hintamuutos, kun vientikysyntä vähenee } \\
\hline $0 \%$ & $0,1 \%)$ & 0,02 & $1,1 \%)$ & 0,25 & $16,3 \%)$ \\
\hline $44 \%$ & $-0,16(-10,5 \%)$ & $-0,14 \quad($ & $-9,3 \%)$ & 0,13 & $8,2 \%)$ \\
\hline $85 \%$ & $-0,61(-39,4 \%)$ & $-0,81 \quad($ & $-51,7 \%)$ & $-0,27 \quad($ & $-17,5 \%)$ \\
\hline \multicolumn{6}{|c|}{ Tulomuutos, kun vientikysyntä vähenee } \\
\hline $0 \%$ & $0,1 \%)$ & $0,94($ & $0,8 \%)$ & $8,01 \quad($ & $6,9 \%)$ \\
\hline $44 \%$ & $-10,27(-8,4 \%)$ & $-9,23$ & $-7,5 \%)$ & $-0,60$ & $-0,5 \%)$ \\
\hline $85 \%$ & $-32,76(-26,7 \%)$ & $-42,29($ & $-34,6 \%)$ & $-17,56$ & $-15,0 \%)$ \\
\hline
\end{tabular}

Mikäli vientikysyntä väheni epidemian alussa enemmän kuin taulukossa 1 raportoiduissa skenaarioissa, olivat alkushokin aiheuttamat muutokset suuremmat. Kun vientikysyntä esimerkiksi keskeytyi kuukauden ajaksi kokonaan ja sen jälkeen jäin puoleen normaaliskenaariosta, olivat keskisuurelle epidemialle simuloidut tulomenetykset 32 miljoonaa euroa puolessa vuodessa. Valmius vientikysynnän muutosten hallitsemiseen tautialueen rajaamisella (eli regionalisoinnilla) vaikuttikin merkittävästi tautivahinkojen suuruuteen. Tulokset viittaavatkin siihen, että menetykset ovat huomattavasti vähäisemmät, mikäli tautialue voidaan rajata pian ensimmäisen tautitapauksen jälkeen.

\section{Johtopäätökset}

Tulokset viittaavat siihen, että tarttuvan eläintaudin leviäminen Suomeen voi aiheuttaa markkinahäiriöiden kautta merkittäviä taloudellisia vahinkoja Suomalaiselle sianlihantuotantoketjulle. Erityisesti pieni ja pitkäkestoinen epidemia näyttää aiheuttavan merkittäviä häiriöitä. Sen sijaan suuri epidemia yhdessä vähäisten tuontirajoitusten kanssa voi aiheuttaa taudin torjuntaan liittyviä kannustinongelmia, sillä sianlihan tuottajahinta voi jopa nousta. Tuottajien kollektiivinen hyötyminen epidemiasta lienee kuitenkin epätodennäköistä, sillä vientikysynnän aleneminen ainakin hetkellisesti lienee todennäköinen vaihtoehto, kun Suomessa havaitaan herkästi leviävää sikatautia.

Tulokset viittaavat siihen, että tautishokin vaikutus ilmenee osittain viiveellä. Siten tautishokki voi vaikuttaa sikamarkkinoihin muutama kuukausi epidemian loppumisen jälkeen. Tautishokin aiheuttamia tulonmenetyksiä voidaan kuitenkin vähentää minimoimalla vientikysynnässä tapahtuvat muutokset. Tulokset viittaavat siihen, että tulonmenetyksiä voidaan vähentää jopa 20-30 miljoonalla eurolla, jos tautialue kyetään rajaamaan erilleen taudista vapaasta alueesta nopeasti ja uskottavasti, ja näin voidaan vakuuttaa suomalaista sianlihaa ostaville maille epidemian olevan hallinnassa. Tulos pätee erityisesti tapauksissa, joissa vientikysynnän odotetaan laskevan suhteellisesti mitaten paljon.

Tulonmenetysten lisäksi epidemian hallitsemiseksi ja taudin hävittämiseksi tehtäviä toimenpiteitä arvioidessaan yhteiskunnan on otettava huomioon kuluttajien hyvinvointimuutokset sekä taudin hallinnasta yhteiskunnalle aiheutuvat kustannukset. Kysynnän muutosten yksityiskohtainen arviointi edellyttääkin, että infektion leviäminen mallinnetaan tarkemmin kuin tässä paperissa on esitetty. Tähän pyrkii MTT taloustutkimuksen ja EELA:n riskinarvioinnin tutkimusyksikön käynnistämä tutkimushanke, jossa mallinnetaan klassisen sikaruton leviäminen Suomessa ja sen aiheuttamat vahingot alueellisesti ja myös pitemmällä aikavälillä.

\section{Kirjallisuus}

van Asseldonk, M.A.P.M., Kuiper, W.E. \& Huirne, R.B.M. 2000. Classical swine fever and price volatility. Julkaisussa: Salman, M.D., Morley, P.S. \& Rush-Gallie, R. (eds.). 2000. Proceedings of the 9th symposium of the International Society for Veterinary Epidemiology and Economics, Beckenbridge, USA, 88-90.

Buijtels, T. \& Burrell, A. 2000. The trade argument for eradicating Aujetzky's disease: Effects of export restrictions on the Dutch pig industry. Tijdschrift Voor Sociaal Wetenschappelijk Onderzoek Van De Landbouw 15: 126-146. 
Dijkhuizen, A. A., Jalvingh, A. W., Berentsen, P. B. M. \& Oskam, A. J. 1979. Modelling the economics of risky decision making in highly contagious disease control. Julkaisussa: Dijkhuizen, A. A. and Morris, R. S. Animal health economics: Principles and appliccations. Sydney: Post graduate foundation in veterinary science, s. $159-170$.

Elbers, A.R.W, Stegeman, A., Moser, H., Ekker, H.M., Smak, J.A. \& Pluimers, F.H. 1999. The classical swine fever epidemic 1997-1998 in the Netherlands: descriptive epidemiology. Prev.vet.med. 42: 157-184; Mangen, M-J.M. 2002. Economic welfare analysis of simulated control strategies for Classical Swine Fever epidemics. PhD thesis, Wageningen agricultural university. $186 \mathrm{p}$.

Mahul, O. \& Durand, B. 2000. Simulated economic consequences of foot-and-mouth disease epi-demics and their public control in France. Preventive Veterinary Medicine 47: 23 - 38.

Pighealth.com. 2003. Classical Swine Fever (CSF) in UK. [Verkkojulkaisu] Viitattu 26.11.2003. Saatavilla internetissä: http://www.swinefile.com/.

OIE. 2001. International animal health code (2001). Viitattu 27.9.2001. Saatavilla internetissä:

http://www.oie.int/eng/normes/mcode/a_summry.htm

Saatkamp, H. W., Berentsen P. B. M. \& Horst, H. S. 2000. Economic aspects of the control of classical swine fever outbreaks in the European Union. Veterinary Microbiology 73: 221-237 